\title{
Campaigning Environmental Conservation During the Pandemic: A Social Media Reception Analysis
}

\author{
Lila Nathania*, Asih Zunaidah, Yanuarita K, Haifa Imansyah and Evan \\ Reinaldo \\ Communication Science Department, Faculty of Economics and Communication, Bina Nusantara University, Jakarta, \\ Indonesia 11480 \\ *Corresponding author email: lila.nathania@binus.edu
}

\begin{abstract}
In modern days, environmental journalism is deemed essential as the issue of global warming is alarming to a greater extent. In response to extreme climate change, scientists urge people around the globe to take an active part in preserving the environment. Before the pandemic, many activists protested on the streets, met people in the malls, invited youngsters to join an environmentalist organization and contribute to conserve the earth along with its wildlife. During the Covid-19, some of these activities have been hindered by the health protocols. This does not mean that activists must retreat from pursuing the cause and stop their efforts: they move to online campaign using the social media. Accordingly, the researchers conducted a reception analysis of environmental conservation campaign contents shared on social media. The study was conducted in a green campus of Malang city, Universitas Brawijaya. The subjects were students from several faculties. The qualitative reception analysis method was employed. This study's results can serve as a guidance for universities in implementing green campus concept and for other organizations campaigning environmental conservation through social media. Additionally, it is expected that the results can reveal the effective message-delivery to the millennials and how well they receive the campaignmessage. It ultimately leads to the primary purpose: to make the millennials take part in conserving the environment on their daily basis.
\end{abstract}

Keywords: Campaigning, Conversation, Social Media

\section{INTRODUCTION}

Climate change is a global environmental problem urging everyone to make a difference at the earliest opportunity. Although many scientific articles discuss climate change as a critical issue, many people are not concerned about it. In 1997, Nkemdirin[1] stated that the world was already at the final threshold for climate change. Some people even believed that the earth had entered the era of global climate change (1997, p. 566). To date, some Indonesian people still doubt the truth of global warming and show little awareness about the issue, even though humans are the leading cause of changes in the composition of the earth's atmosphere that trigger climate change (Intergovernmental Panel on Climate Change, 2007) ${ }^{[2]}$. A poll on environmental awareness conducted by the YouGov-Cambridge Globalism Project in 23 countries put Indonesia in the lowest position: $18 \%$ of Indonesians did not believe in human-caused climate change (Milman, 2019)[3].

Covid-19 has substantially impacted the environment as people are restricted from going outside to prevent the virus from spreading. Research proved that the earth is healing due to improved air quality all over the globe (Lian et al., 2020, Zangari et al., 2020, Siciliano et al., 2020, Kaniah et al., 2020)[4]-[7]. The results show that humans' reduced activities led to a decreased level of pollutions. Environmental research and journalism have been trying to convince us that humans can still help recover the earth. Since the 1990 s, media reporters have become aware of the importance of campaigning for nature conservation. In the 90s, many environment-specialist reporters displayed data, assisted by the internet and professional organizations such as the Society of Environmental Journalists (Senecah, 2004, p. 188)[8]. In the early 1990s, a senior journalist stated that environmental journalism did not only discuss pollution and living things but also land management, sustainability, climate change, new technologies such as hybrid cars, energy efficiency, invasive species, and many more (Senecah, 2004, p.192)[8]. Thus, environmental journalism is developed to improve ways of life, preventing harm to nature. Along with increasing public awareness of the environment, activists campaign to encourage people to reduce waste, limit energy consumption, and use harmless substances (Lee, 2013, p. 731)[9]. 
The pandemic has reshaped normality: various activities go digital. Before the pandemic, many environmental campaigns were done before a crowd or on the street. Some also went with a door-to-door or house-to-house approach, although campaigning online was also an option. As health protocols restrict activities involving crowds or direct human contacts, activists resort to digital campaigns. Correspondingly, environmental journalism is closely related to social media. Many activists turn to social media and begin to leave the old media, such as newspaper, radio or TV news. Cooper stated that social media had changed the culture a lot. Sites like Facebook and YouTube have grown in popularity since their introduction in 2007. Today, more than $73 \%$ of adults have at least one social media account, and $42 \%$ have at least two (Cooper, 2015, p. 112-113)[10]. Newspapers, TV, and radio are accessed less frequently because they have limited broadcast time and pages or duration, unlike social media, which can be accessed anytime and anywhere (Lestari \& Purnama, 2017, p. 32)[11]. Young people much prefer this borderless media. Based on a survey conducted by We Are Social and Hootsuite, the most popular social media in Indonesia are YouTube, Facebook, Instagram, and Twitter (2019, Pertiwi)[12].

Although social media is popular and used by people of all ages, the largest users are millennials who like to consume various kinds of content from digital platforms (Cooper, 2015, p. 113)[10]. In the United Kingdom, $40 \%$ of millennials admit that they have the most difficulty disconnecting from their cell phones than all other media types; this technology dependency level sets them apart from other groups (Ofcom, 2012)[13]. The millennials are born between 1982 - 2005. This generation is the largest globally, with a total number of more than 80 million (Cooper, 2012, p. 3)[14]. Millennials, especially those with higher education levels, become our hope to preserve nature actively. They will be affected if they cannot protect the environment, along with future generations. Environmental issues are highly relevant in the current situation. This study used millennials as research subjects, considering their age and importance level in the environmental conservation movement. The researchers selected Universitas Brawijaya students because of its green campus concept since 2015 (LPM Perspective, 2017)[15]. Social media was chosen based on its popularity among millennials; they tend to access information or news content from various social media because of the easy access and flexibility.
A few previous studies addressed social media related to environmental conservation. Sogari and his research team (2017)[16] perceived social media's role in wine consumption behaviour among millennials and non-millennials in their research entitled 'Millennial Generation and Environmental Sustainability: The Role of Social Media in the Consumer Purchasing Behaviour for Wine'. The analysis of 2,597 samples shows that products with environmentally friendly values and advertised through social media were preferred and chosen by millennial and non-millennial consumers. Moreover, Ogunjinmi (2016)[17] conducted research entitled 'Influence of Social Media on Climate Change Knowledge and Concerns' in Nigeria and found that social media had a positive effect on increasing knowledge and awareness of climate change among the users; government organizations and NGOs can use social media to carry out campaigns as this method has proven successful in Nigeria. Additionally, Williams and her research team (2014)[18] asserted, in their research entitled 'Green Sustainability and New Social Media', that many organizations use environmentally friendly campaign strategies to gain public sympathy without having clear standards and goals; this research looks at how social media is a new channel to campaign for environmental sustainability effectively.

On this background, millennials, as avid social media users, have an essential role in conserving the earth and its wildlife. Previous studies did not specifically analyze how the millennials received the campaign message. They mostly addressed the effects of social media in environmental campaigns; thus, we analyzed whether millennials studying at a university holding the green campus concept had a good reception of environmental conservation messages on social media. Research on social media content is essential because the findings can be used as a reference to find out whether environmental journalism strategies in social media works effectively and the messages are well-received by the students or millennials at large.

\section{LITERATURE REVIEW}

A few theories are reviewed to support the data analysis of this study: reception analysis, environmental conservation message, and social media.

\subsection{Reception Analysis}

According to Hall, the media possess great power: they can determine what the public needs to know (quoted in West \& Turner, 2014, p. 443)[19]. Woordward (1997)[20] added that media have the 
power to determine whether an issue is considered important or unimportant to inform; they can make something ordinary to extraordinary (quoted in West \& Turner, 2014, p. 443)[19]. Based on this theory, the public will pay attention to any issue raised by the media because they considered it important, despite the public reception might not be all positive. Conceptually, media consumption is diverse according to the audience's individual needs; thereby, each individual's reception is subjective, and the result can vary (Hadi, 2009, p. 2)[21]. The media have tremendous power to determine the topics to raise and publish; they can also dictate the contents that the public need to read or watch. Nonetheless, the message reception depends on each individual. The audience can interpret and behave by their choice based on the meaning generated by the media content they consume (Hadi, 2009, p. 2)[21]. Reception analysis focuses on each individual's uniqueness as a media audience; their intellectual level and abilities are essential in this study (Baran \& Davis, 2006)[22]. Therefore, the informants in this study were purposively selected because it would greatly determine the results.

\subsection{Environmental Conservation Message}

Climate change has been discussed globally for the last few decades. Some people might be aware of this issue after watching the film 'An Inconvenient Truth' (2006), although climate change started to receive attention in the 1990s. In 1997, Nkemdirin stated that the world was already at the final threshold for climate change; some people even believed that the earth had entered the era of global climate change (1997, p. 566)[1]. Unfortunately, some people still do not care about this critical problem. Many studies have proven that humans are the leading cause of changes in the composition of the earth's atmosphere, triggering climate change (Intergovernmental Panel on Climate Change, 2007)[2]. Public awareness is still relatively low, especially in countries where scientific development is advanced. A poll conducted by the YouGovCambridge Globalism Project in 23 countries shows that Indonesia's public awareness of climate change is the lowest compared to 22 other countries. It is an unexpected finding because media reporters have been aware of the importance of campaigning for nature conservation since the 1990s; many specialist reporters who are the experts of the issue displayed the data, assisted by the internet and professional organizations such as the Society of Environmental Journalists (Senecah, 2004, p. 188)[8]. In the early 1990 s, a senior journalist stated that environmental journalism had developed; it discussed not only pollution and living things but also land management, sustainability, climate change, new technologies such as hybrid cars, energy efficiency, invasive species, and others (Senecah, 2004, p.192)[8]. However, the development of environmental journalism in Indonesia is not as advanced as in other countries, leading to low public awareness of environmental issues. Consequently, various environmental conservation contents are widely distributed through conventional and digital media, mostly nature-related campaign in nature, which commonly invites the public to do something for the earth. Many organizations, government agencies, artists, and activists campaign for environmental conservation through social media accounts. These contents can widely affect social media users because they can easily be found and accessed.

\subsection{Social Media}

Social media is a virtual place containing blogs, forums, social networks, and other sites where people can connect and share content; its interactive communication allows messages to be shared among individuals, audiences, organizations, and other public sectors (Grljević \& Bošnjak, 2014, p. 266)[23]. Consequently, various news or information are widely shared, including contents about climate change, pollution, and sustainability. On social media such as Facebook, Instagram, YouTube, and Twitter, everyone can read the news, share information, and interact with other people. Since 2007, sites such as Facebook and YouTube have increased their popularity dramatically. Based on a survey conducted by We Are Social and Hootsuite, the most popular social media in Indonesia are YouTube, Facebook, Instagram, and Twitter (2019, Pertiwi)[12]. Moreover, 73\% of adults have at least one social media account, and $42 \%$ have at least two (Cooper, 2015, p.112113)[10]. 


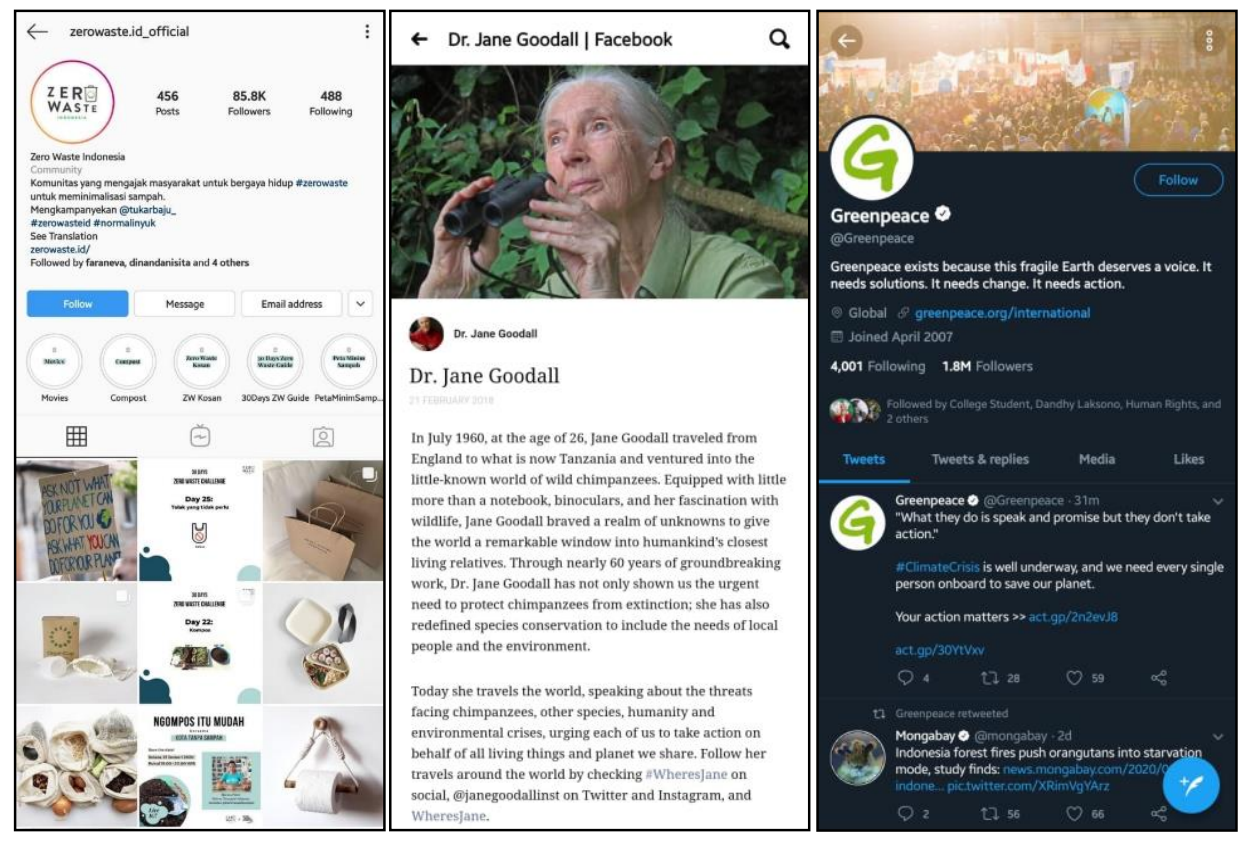

FIGURE 1. Social media accounts campaigning environmental conservation

The four most popular social media in Indonesia have many contents related to environmental conservation. Many people or organizations campaign for a sustainable lifestyle. The social media accounts shown in Figure 1 belong to Jane Goodall's Facebook, Greenpeace's Twitter, and Zero Waste Indonesia's Instagram. They are public figures and organizations highly active in posting environmental conservation messages. Social media is worth studying because this new media can inspire and change human behavior, including purchasing decisions (of a product) and social changes (Mahoney \& Tang, 2017, p.1)[24]. Examining audience reception of environmental conservation contents shared on social media is relevant to current conditions.

\section{RESEARCH METHODS}

This research used a qualitative descriptive approach. Qualitative research aims to understand the social problems described in detail and comprehensively; it also describes research subjects/informants' perspectives in detail (Cresswell, 2003)[25]. Descriptive qualitative research describes the reality and nature of the population being studied systematically, factually, and accurately without explaining the relationship between variables. The researchers conducted a reception analysis aiming to examine the meaning creation of media discourse focusing on media viewers or audiences' experience (Jensen, 2003)[26].
Hadi asserted that the reception analysis concept creates meaning in the interaction between the audience (audience/reader/listener) and the media text. Meaning is not attached to the media text but is created because of the public's interpretation of the text $(2009$, p.2)[21]. The same text message can be received differently by audiences with different experiences, cultures, and values; it is not always well-received as the journalist/content creator expects.

\subsection{Research Location}

The research was conducted at Universitas Brawijaya, in Malang City, East Java. The location was determined considering that Universitas Brawijaya has been operating with the green campus concept since 2015 (LPM Perspective, 2017)[15]. It was assumed that its students (who were millennials) were aware of environmental conservation activities.

\subsection{Data Collection}

This study used primary and secondary data: primary data were collected through in-depth interviews with research subjects, while secondary data were obtained from research journals. Researchers conducted in-depth interviews with the subjects to explore the information needed for the primary research data. The research subjects were determined through a purposive sampling method under the following criteria: (1) millennials (born in 1982-2005), (2) students of Universitas Brawijaya, (3) avid users of social media, and (4) being aware 
of environmental conservation activities. In addition, the researchers conducted studies on scientific journals to obtain secondary research data.

In the primary data, the subjects were interviewed using Zoom Meeting due to the pandemic's health protocols. Five people were selected based on the answers they had filled in the Google Form. This study used 26 subjects; however, the research team only selected five people with complete and unique answers for further interviews; each represented all subjects' answers in the Google Form. Thus, the data analyzed can reflect the uniqueness of the five interviewees and represent the general answers of 21 other informants. Aside from conducting interviews with Universitas Brawijaya students, the researcher also conducted an interview with a lecturer of the faculty of Culture Studies as a cross-reference for students' interview responses.

\subsection{Data Analysis}

After the interviews, the data obtained was saturated and analyzed. The interview results were put into Stuart Hall's (1980) encoding - decoding categories. There are three kinds of audience positions in the decoding process of media messages (West \& Turner, 2014)[19]:

1. Dominant-hegemonic Position

The audience received media messages well. The media was successful in conveying messages. The audience was affected and showed behavioral changes. So, the media and audience had the same ideas and concepts on the issue being discussed.

2. Negotiated Position

The message was received and understood well, but the audience made several adjustments and did not receive/accept everything completely. Cultural values were reconsidered to fit the message displayed by the media. People accepted only part of media content or believed in media content but chose not to take any action.

3. Oppositional Position

With critical thinking or specific considerations, the audience did not want to accept the media's message. They chose to believe other ideas or concepts.

Based on this classification, the research team concluded Universitas Brawijaya students' reception of environmental conservation content on social media; it can be used as a reference for social media content creators to create attractive and effective environmental conservation campaigns for millennials.

\subsection{Data Triangulation}

Triangulation is essential in research to make the results valid and reliable. Denzin \& Lincoln (2009)[27] stated that triangulation utilizes various perceptions to clarify meaning and verify the possibility of repetition of observations even though the principle remains that there are no $100 \%$ repeatable observations or interpretations. This research used triangulation in data sources: data obtained from several informants were collected, analyzed, and the conclusion was made from the results. Sugiyono asserted that using several informants in research is included as sources triangulation (2011, p. 273)[28].

\section{Research Results}

After collecting and triangulating the data, they were analyzed and categorized into audience positions in the decoding process of media messages proposed by West \& Turner (2014)[19].

\subsection{The Interview Results}

It was found that $46 \%$ of the subjects were dominanthegemonic, $54 \%$ were negotiated, and no one was in the opposition. As for the in-depth interviews, the researchers purposively selected five subjects and interviewed them via Zoom meetings. This finding is in line with Woodward (1997)[20], asserting that the audience will consider an issue necessary if the media decide it necessary. All subjects agreed that environmental issues were important and had to be dealt with cooperatively; they agreed with the mass media and social media messages. Environmental conservation contents on social media are proven to positively affect the daily life of people reading them. In this study, the subjects stated that they experienced behavioral changes. Some chose to use environmentally friendly objects such as water tumblers, some invited their friends to live more environmentally friendly, and some wanted to start an environmentally friendly business. It shows that exposure to environmental conservation content from the media positively affects a person's life. 


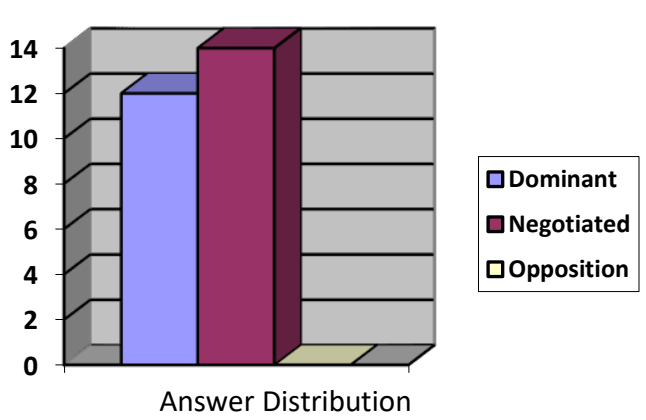

FIGURE 2. The Distribution of Informants' Answers

The five interviewed subjects were divided into two categories: dominant-hegemonic (receiving the message well along with behavioral change) and negotiated (receiving the message well but taking no further actions). It was found that three people were in the dominant-hegemonic category, and two were in the negotiated category; this diversity emerged as the subjects consumed media in various ways and needs. Each individual's acceptance was subjective, and the result varied. The media might have the power to shape public opinion on the importance of environmental issues; however, each subject's acceptance and attitude were different due to diverse ways and motivation of media consumption. People interested in and actively seeking environmental news are certainly more hegemonic than those reading contents about the environment due to external force.

4.1.1. Dominant-Hegemonic. A dominanthegemonic position is when a person receives the media message entirely, from the cognitive stage to behavior change. Three subjects were in this category, as explained in the following summary:

Audhita Palupi (AP):

$\mathrm{He}$ is aware of environmental conservation and always brings his water bottle to campus. He also reduces the use of disposable plastics that pollute the environment as much as possible. AP is also willing to donate to environmental organizations such as WWF and Greenpeace at any given opportunity. AP shares environmental news with his closest friends and asks them to use reusable shopping bags.

Muhammad Zultanpragas (MZ):

$\mathrm{He}$ is the subject who cares most about the environment and has the strongest position in the dominant-hegemonic category. He is the only one actively accesses news about the environment, such as the case of microplastic pollution. He often invites his family and friends to participate in environmental action, even though they do not always respond well.
MZ even has plans to work in sustainability; he has many ideas to work by processing waste creatively. Kalfin Annisa (KA):

Among all the subjects interviewed, KA is the only one following artists, influencers, and environmental organizations on social media. Since high school, she has been aware of environmental issues and has taken actions such as using stainless steel straws and environmentally friendly shopping bags. Her family and friends also care about environmental issues. She also often shares environmental news on her social media.

\subsubsection{Negotiated.}

A person is categorized in the negotiated position when he receives media messages partially, is not completely affected, and indirectly contributes to his behavior change. Two subjects were in this category, as explained in the following summary:

Alyza Zahra (AZ):

AZ used to not care about the environment. However, after being a university student, she has been active in an organization whose programs required the members to seek, study, and practice environmental action actively. For AZ, it is burdensome as she has to change her habits. Neither her family nor her friends are aware of environmental issues. AZ explained that the green campus concept and her organizational activities encouraged her to change, although involuntarily. AZ does not actively seek environmental content since she does not find it interesting, but sometimes she reads environmental content because she considers fighting global warming worthwhile.

Yohana Hartya (YH)

$\mathrm{YH}$ understands that the green campus concept is useful; she agrees that we all need to make environmental conservation efforts. However, she never actively looks for environmental content on social media. Some of her actions were based on other purposes, not nature conservation; for example, bringing a water tumbler to campus means free water-refill (economic reason). She liked a friend's post about the environment just because of competition (to support her friend). YH said that it was good to clean the campus to prevent flooding and earn money from selling the trash (economic reason). When buying environmentally friendly goods, YH considers the environment and the goods' quality. 


\subsubsection{Opposition.}

No subjects were in the opposition; although not all of them entirely accepted and understood the message of environmental conservation, they realized that it was a good action, and the issue was real. They did not change their behavior entirely and immediately but admitted that they were slowly changing, at least by reducing the use of disposable plastics.

\section{DISCUSSION}

Based on the results, the discussion is grouped into four main topics: environmental awareness, social media, behavior change, and the effectiveness of the green campus concept.

\subsection{Environmental Awareness}

Based on data processing results, the researchers found that environmental awareness did not commensurate with the intensity of environmental conservation news consumption. Among the three interviewed subjects in the dominant-hegemonic category, one person accesses his social media to look for environmental conservation news from time to time, while the others read the news only when the it randomly pops up in his social media feed. Interest in environmental issues did not directly indicate a considerable effect on behavioral change; it does not mean that people interested in environmental issues would actively and voluntarily read news about the environment on social media or other mass media. However, people interested in the environment generally wanted to choose or read more about environmental-related advertisements on their social media feeds. Although no subjects actively sought out news about the environment, one of them stated that she followed several accounts related to environmental conservation to automatically update and keep informed about the latest environmental issues by reading news shared by people or organizations actively campaigning. Most of the subjects read the news because it appeared as an advertisement.

From Google Form responses, all 26 subjects agreed to the importance of environmental-issues awareness, although most of them were in the negotiated category. If seen from a poll conducted by YouGov-Cambridge Globalism Project, resulting in Indonesians have the lowest awareness of climate change compared to 22 other countries, this finding is quite encouraging. Hypothetically, students in a green campus have more knowledge about the importance of saving the environment than those who have not been exposed to environmental news or issues; these people might not care because they are unaware of the issue.

\subsection{Social Media}

All of the research subjects had preferences when consuming environmental conservation messages on social media. They did not read all the news despite knowing the importance of environmental issues. They selected the news based on their preferences or those they found interesting. Some subjects stated that audio-visual is essential; they preferred news presented through attractive images or videos, and they found long articles less enjoyable to read. From the interviews, Instagram was the common social media that the subjects accessed for environmental news or people they followed as many famous figures start campaigning about environmental conservation. Social media is an excellent platform for reaching out to the millennials and exposing the latest news about the environment.

\subsection{Behavioral Change}

As found in the interview results, surrounding people do not affect a person's decision to care about the environment. Some of the subjects, family, and friends cared about the environment, while some were utterly ignorant. Despite surrounded by unaware people, some subjects cared about the issues. The ignorant family or friends did not prevent them from saving the earth or planning an environmentally friendly business. Another finding indicated that self-motivation and awareness was not the only reason to care about the environment; some subjects used to be unaware before joining a campus organization campaigning environmental awareness, which required them to read news related to environmental issues. After being exposed, they changed their behavior and took part in environmental campaigns. However, some behavioral changes were not due to the subjects' awareness; they brought reusable water bottles just to get free water refills or reduced using disposable plastics because of the campus's regulations. Thus, we found several motives behind the behavioral changes: self-awareness, external force (regulation), and economy.

\subsection{The Effectiveness of The Green Campus Concept on Environmental Awareness}

All of the subjects agreed that the green concept campus is a good cause and beneficial. However, the practices have been carried out inconsistently and not taken seriously, leading to ineffectiveness. The subjects said that there were very few posters/billboards/announcements displaying the 
green campus concept. The students were not informed or invited to activities reflecting environmental conservation awareness; the lecturers did not specifically inform the concept in classes. So, the concept was not well distributed. As a crosschecking, the researchers interviewed some lecturers of several faculties. The students' answers were confirmed from the responses: only a few places on campus had posters/banners about Universitas Brawijaya being a green campus.

In addition, the university has not implemented the 'green' regulations consistently; for example, the campus cafeteria prohibited the use of disposable plastic spoons/plates but only for a short time. Now, the regulation is no longer implemented. Moreover, the green regulations were mostly applied to lecturers or campus staff, not to the students. They were required to send digital documents instead of printed ones or bring individual water bottles to the office. Students were only informed about the regulations whenever they planned an event, which means only those related to the event applied them. Thus, it was not self-awareness; it was an external force.

Regarding the effect of being students in a green campus on environmental awareness, some of the subjects stated that the concept did not affect their decision or awareness, as they had already been aware of the issue even before they became a college student. Some subjects argued that Malang city and their friends' nature were the reasons for their awareness; Malang has cool and fresh air, and it would be great if other big cities have the same environment. Having friends aware of the environment also helped change their decision and behavior. Social media also has an essential part in this matter.

\section{CONCLUSION}

Based on the results and discussion, there are several conclusions related to the Reception Analysis of Environmental Conservation Messages on Social Media conducted to Universitas Brawijaya students:

- Based on the results, it was found that $46 \%$ of the subjects were in a dominant hegemonic position (when a person receives the media message entirely, from the cognitive stage to behavior change), and $54 \%$ were in a negotiated position (when a person receives media messages partially, is not entirely affected, and indirectly contributes to his behavior change).

- The subjects' environmental awareness did not commensurate with the intensity of environmental conservation news consumption (based on the in-depth interview results). Interest in environmental issues did not directly indicate a considerable effect on behavioral change; it does not mean that people interested in environmental issues would actively and voluntarily read news about the environment on social media or other mass media. However, people interested in the environment generally wanted to choose or read more about environmental-related advertisements on their social media feeds.

- The subjects consumed social media based on their particular preferences or issues they considered interesting; thus, they might not read environmental news because they were not interested.

- A behavioral change occurred when the subjects deemed it necessary. Even though their family or friends care about the environment, they would still ignore the issue if deemed unnecessary.

- The green campus concept has not been effective as it is not taken seriously and consistently; very few posters/billboards/bulletin boards display the information regarding Universitas Brawijaya carrying a green campus concept. There has not been information requiring students to do certain things as a form of conserving the environment.

\section{ACKNOWLEDGMENTS}

This work is supported by Research and Technology Transfer Office, Bina Nusantara University as a part of Penelitian Terapan Binus entitled 'Analisis Penerimaan Mahasiswa Universitas Brawijaya terhadap Pesan Konservasi Lingkungan di Media Sosial' with contract number: No: 025/VR.RTT/IV/2020 and contract date: 6 April 2020 .

\section{REFERENCES}

[1] L. Nkemdirin, "Climate Change 1995: The Science of Climate Change," 1997.

[2] Intergovernmental Panel on Climate Change, Climate Change 2007: Physical Science. New York: Cambridge University Press, 2007.

[3] O. Milman, "US is hotbed of climate change denial, major global survey finds," The Guardian, 2019. https://www.theguardian.com/environment/ 
2019/may/07/us-hotbed-climate-changedenial-international-poll (accessed Jan. 22, 2020).

[4] X. Lian, J. Huang, R. Huang, C. Liu, L. Wang, and T. Zhang, "Impact of city lockdown on the air quality of COVID-19hit of Wuhan city," Sci. Total Environ., 2020.

[5] S. Zangari, D. T. Hill, A. T. Charette, and J. E. Mirowsky, "Air quality changes in New York City during the COVID-19 pandemic," Sci. Total Environ., 2020.

[6] B. Siciliano, G. Dantas, C. M. da Silva, and G. Arbilla, "Increased ozone levels during the COVID-19 lockdown: Analysis for the city of Rio de Janeiro, Brazil," Sci. Total Environ., 2020.

[7] K. D. Kanniah, N. Zaman, D. Kaskaoutis, and M. Latif, "COVID-19's impact on the atmospheric environment in the Southeast Asia region," Sci. Total Environ., 2020.

[8] S. L. Senecah, The Environmental Communication Yearbook. New Jersey: Lawrence Erlbaum Associates, 2004.

[9] T. Lee and S. van de Meene, "Comparative studies of urban climate co-benefits in Asian cities: an analysis of relationships between $\mathrm{CO} 2$ emissions and environmental indicators," J. Clean. Prod., vol. 58, pp. 1524, 2013.

[10] N. Cooper, "7 Tips for Using Social Media to Reach Patients of All Ages," Dental Products Report, 2015. https://www.dentalproductsreport.com/view /7-tips-using-social-media-reach-patientsall-ages (accessed Jan. 22, 2020).

[11] M. T. Lestari and H. Purnama, "Social Media Usage by Teen Segmented Commercial Private Radio in Bandung," SHS Web Conf., 2017.

[12] W. K. Pertiwi, "Facebook jadi Medsos Paling Digemari di Indonesia," Kompas.com, 2019. https://tekno.kompas.com/read/2019/02/05/ 11080097/facebook-jadi-medsos-palingdigemari-di-indonesia?page $=$ all (accessed Jan. 23, 2020).

[13] Ofcom, "Adults' Media Use and Attitudes Report," stakeholders.ofcom.org.uk, 2018. http://stakeholders.ofcom.org.uk/binaries/re search/media-literacy/media-useattitudes/adults-media-use-2012.pdf (accessed Jan. 22, 2020).

[14] R. Cooper, "The Millenial Generation:
Research Review," Natl. Chamb. Found., 2012, [Online]. Available: https://www.uschamberfoundation.org/repo rts/millennial-generation-research-review.

[15] LPM Perspektif, "Usung Konsep Green Campus, WR IV Mengakui Bangunan di UB Tidak Smart Building," lpmperspektif.com, 2015.

https://pmperspektif.com/2017/03/26/usun g-konsep-green-campus-wr-iv-mengakuibangunan-di-ub-tidak-smart-building/ (accessed Jan. 23, 2020).

[16] G. Sogari, T. Pucci, B. Aquilani, and L. Zanni, "Millennial Generation and Environmental Sustainability: The Role of Social Media in the Consumer Purchasing Behaviour for Wine," Sustainability, vol. 9, 2017.

[17] A. A. Ogunjinmi, O. R. Sunday, K. O. Ogunjimi, and O. E. Adekoya, "Influence of Social Media on Climate Change Knowledge and Concerns," Niger. J. Agric. Food, Environ., vol. 12, no. 4, 2016.

[18] K. C. Williams, R. A. Page, and A. R. Petrosky, "Green Sustainability and New Social Media," J. Strateg. Innov. Sustain., vol. 9, no. 1, 2014.

[19] R. West and L. H. Turner, Introducing Communication Theory: Analysis and Application. Singapore: McGraw-Hill Education, 2014.

[20] K. Woodward, Identity and Difference (Culture, Media and Identities series), 1st ed. Milton Keynes, UK: SAGE Publications Ltd, 1997.

[21] I. P. Hadi, "Penelitian Khalayak dalam Perspektif Reception Analysis," J. Ilm. Scriptura, vol. 3, no. 1, 2009.

[22] S. J. Baran and D. K. Davis, Mass Communication Theory: Foundation, Ferment, and Future. California: Thomson Wadsworth, 2006.

[23] O. Grljević and Z. Bošnjak, "Utilization of Internet Social Media Sites: Students' Perspective," CBU Int. Conf. Innov. Technol. Transf. Educ., 2014.

[24] L. M. Mahoney and T. Tang, Strategic Social Media. United Kingdom: John Wiley \& Sons Ltd., 2017.

[25] J. W. Creswell, Research Design: Qualitative, Quantitative, and Mixed Methods Approaches. SAGE Publications Ltd, 2003.

[26] K. B. Jensen, A Handbook of Media and 
Communication Research, Qualitative and Quantitative Methodologies. London: Routledge, 2002.

[27] N. K. Denzin and Y. . Lincoln, Handbook of Qualitative Research, Bahasa Ind. Yogyakarta: Pustaka Pelajar, 2009.

[28] Sugiyono, Metode Penelitian Kuantitatif, Kualitatif dan $R \& D$. Bandung: Alfabeta, 2011. 